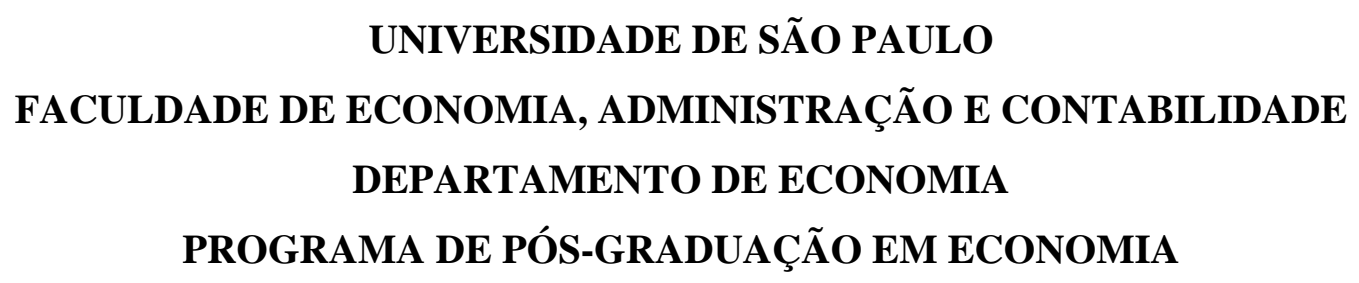

EMPRÉSTIMOS BANCÁRIOS E OPERAÇÕES DE REDESCONTO: UM ESTUDO SOBRE MODELOS DE DEMANDA PARA INSTITUIÇÕES FINANCEIRAS

Sérgio Mikio Koyama

Orientador: Prof. Dr. Márcio Issao Nakane

SÃO PAULO 
Profa. Dra. Suely Vilela

Reitora da Universidade de São Paulo

Prof. Dr. Carlos Roberto Azzoni

Diretor da Faculdade de Economia, Administração e Contabilidade

Prof. Dr. Joaquim José Martins Guilhoto

Chefe do Departamento de Economia

Prof. Dr. Dante Mendes Aldrighi

Coordenador do Programa de Pós-Graduação em Economia 
SÉRGIO MIKIO KOYAMA

\section{EMPRÉSTIMOS BANCÁRIOS E OPERAÇÕES DE REDESCONTO: UM ESTUDO SOBRE MODELOS DE DEMANDA PARA INSTITUIÇÕES FINANCEIRAS}

Tese apresentada ao Departamento de Economia da Faculdade de Economia, Administração e Contabilidade da Universidade de São Paulo como requisito para a obtenção do título de Doutor em Economia.

Orientador: Prof. Dr. Márcio Issao Nakane

\section{SÃO PAULO}


Tese defendida e aprovada no Departamento de Economia da Faculdade de Economia, Administração e Contabilidade da Universidade de São Paulo - Programa de Pós-Graduação em Economia, pela seguinte banca examinadora:

\section{FICHA CATALOGRÁFICA}

Elaborada pela Seção de Processamento Técnico do SBD/FEA/USP

Koyama, Sérgio Mikio

Empréstimos bancários e operações de redesconto: um estudo sobre modelos de demanda para instituições financeiras / Sérgio Mikio Koyama.

-- São Paulo, 2007.

$258 \mathrm{p}$.

Tese (Doutorado) - Universidade de São Paulo, 2007

Bibliografia.

1. Bancos - Economia 2. Crédito 3. Modelos lineares 4. Demanda Modelos I. Universidade de São Paulo. Faculdade de Economia, Administração e Contabilidade II. Título. 
À minha dedicada esposa Mitti, fonte de minha inspiração e à minha família, berço de minhas forças. 
O trabalho enobrece o homem. É nele que se faz perceber a importância da família e dos amigos. Nenhum trabalho pode ser concluído com êxito sem o apoio de alguém. Neste trabalho, não faltaram apoios, quer seja da família, dos amigos, dos colegas de trabalho. Primeiramente, agradeço ao meu orientador, colega de trabalho e amigo Prof. Dr. Márcio Issao Nakane, a quem devo o apoio e incentivo para o início, execução e conclusão desta tese, bem como as valiosas contribuições, não apenas do ponto de vista técnico, mas de postura acadêmico-científica que guardarei de agora em diante. Também tenho muito a agradecer a minha paciente esposa Mitti Ayako H. Koyama que tanto me apoiou, quer seja nas diversas revisões para esta versão final, quer seja nas discussões metodológicas. À minha família, pelo apoio nos momentos difíceis e pela minha ausência. Agradeço também ao Banco Central do Brasil, em especial a Cornélio Farias Pimentel pela disponibilização das bases de dados necessárias para a construção dos modelos e a Tony Takeda, Eduardo Luis Lundberg, Fani Lea Bader e Fernando Augusto da Cruz Paião Umezú que tanto me apoiaram no tratamento e crítica destas informações. Ao prof. Dr. Júlio da Motta Singer e Prof. Dr. Paulo Picchetti pelas valiosas contribuições para a elaboração deste documento. Aos amigos Ana Maria Saul, José Cleber de Freitas, Sérgio Vasconcelos de Luna, Maria de Lourdes Rocha, Pedro Pontual e Terezinha Pontual que com sua experiência e apoio muito contribuíram, ainda que indiretamente, para a conclusão deste trabalho. A todos que ajudaram nesta empreitada e que por um lapso de memória de minha parte, injustamente não foram citados. 


\section{RESUMO}

A identificação dos fatores que influenciam o processo de escolha do tomador na demanda por crédito apresenta não apenas um interesse mercadológico, mas também em termos acadêmicos e para o formulador de políticas públicas, buscando determinar os impactos de uma decisão que influencia o ambiente macroeconômico, bem como o comportamento dos agentes. Nestes termos, os modelos tradicionais de análise da demanda muitas vezes apresentam suposições pouco realistas e bastante restritivas, necessárias para o processo de estimação dos parâmetros de interesse. Os Modelos Lineares Generalizados Mistos com Variáveis Latentes (GLLAMM) constituem uma classe de modelos que abrangem os tradicionais modelos lineares generalizados e os modelos lineares generalizados mistos, possibilitando uma maior flexibilidade na combinação de um processo de escolha discreta com a determinação dos valores demandados de forma contínua, não impondo um processo único para todas as instituições analisadas, nem tão pouco do processo de escolha. Esta classe de modelos foi aplicada para estudar a demanda por empréstimos bancários utilizando-se informações de uma rica base de dados, a Central de Risco de Crédito do Banco Central. Assim, foi possível a identificação de variáveis como a duração da operação e a classificação de risco da operação que apresentam uma maior relevância no processo de escolha do banco, enquanto que outras, como as garantias, mostraram-se mais importante no volume a ser demandado. A identificação de nichos específicos de algumas instituições foi possível a partir desta análise.

A flexibilidade desta classe de modelos também foi utilizada no intuito de se identificar os fatores que influenciam a demanda por crédito pelos bancos nas operações de redesconto, tendo conseguido tratar o problema de superdispersão ocasionado pelo excesso de zeros neste conjunto de dados. Adicionalmente, tanto efeitos diretos quanto indiretos da taxa de redesconto foram possíveis de serem estudados a partir da inclusão de efeitos aleatórios tanto no intercepto, possibilitando a incorporação de efeitos específicos de cada instituição financeira, bem como nos coeficientes, captando comportamentos individuais de cada banco frente a um mesmo estímulo. 


\begin{abstract}
The aim of this study is to identify the variables that affect borrower's decision-making process through the estimation of loan demand equations. This research is relevant not only for market practitioners, but also to academics and to policy-makers, concerned with the evaluation of possible impacts of decision on the economic environment and on the agent's behavior. Traditional models for demand estimation make unreasonable and very restrictive assumptions to estimate the parameters of interest. Generalized Linear Latent and Mixed Models (GLLAMM) constitute a class of models that includes the traditional Generalized Linear Models (GLM) and Generalized Linear Mixed Models (GLMM), which offer more flexibility and they are particularly suitable to situations that combine discrete choice with continuous decisions. Therefore, we can estimate individual equation for each bank simultaneously. This class of models was applied to study the demand for bank loans using a rich dataset provided by the Central Bank's Credit Risk Bureau. Among the analyzed variables, the loan maturity and the credit risk classification were important in the bank choice while warranties were important in the decision related to the amount borrowed. Moreover, we could also identify specific market segments for some banks. The flexibility of this class of models was also used to identify the factors affecting the demand for overnight funds by commercial banks. This model overcomes overdispersion problems caused by excess of zeros found in the dataset. Additionally, we identified the direct and indirect effects of rediscount rate through the inclusion of random effects in the intercept (incorporating specific effects for each bank) and other coefficients (identifying individual behavior of each bank regarding the same stimuli).
\end{abstract}

